\title{
A macroscopic comparison study on main branches of arteria brachialis and arteria subscapularis in Southern Karaman and Hasak sheep breeds
}

\author{
H. Kara'1ㅁ, Z. Özüdogru², H. Balkaya', D. Özdemir ${ }^{1}$ \\ ${ }^{1}$ Department of Anatomy, Faculty of Veterinary Medicine, Ataturk University, Erzurum, Turkey \\ 2Department of Anatomy, Faculty of Veterinary Medicine, Aksaray University, Aksaray, Turkey \\ [Received: 24 January 2020; Accepted: 10 May 2020]
}

Background: The Southern Karaman sheep, which is very fertile in terms of meat and milk production and is often preferred in livestock raising, is known as a domestic sheep breed. The Hasak sheep is a breed formed by the triple crossbreeding of the German Black-headed, Hampshire and Akkaraman breeds. Arterial feeding of the forelimb is provided by arteria axillaris, a continuation of arteria subclavia. In this study, it was aimed to examine the forelimb arteries in Southern Karaman and Hasak sheep breeds.

Materials and methods: Totally, 8 Southern Karaman and 8 Hasak sheep were obtained from Konya Bahri Dagdas International Agricultural Institute. The sheep were anesthetised with xylazine and ketamine and extravasated by cutting the arteria carotis communis in the neck area of the sheep. The forelimbs of the sheep separated from the body were fixed in 10\% formaldehyde solution and then dissections were made and the course and branching of the arteries were examined. Results: It was determined that the arteria brachialis was divided into two main branches as distal arteria brachialis and proximal arteria subscapularis at the articulatio humeri level of the arteria axillary. Arteria mediana, which is a continuation of arteria brachialis, was also examined in different parts of antebrachium and ended by splitting into branches.

Conclusions: According to the findings of the Southern Karaman and Hasak sheep breeds, it was determined that the forelimb arteries had some anatomical differences but were similar in structure to many sheep breeds. (Folia Morphol 2021; 80, 2: 297-301)

Key words: arteria, axillaris, brachialis, subscapularis, fore limb, sheep

\section{INTRODUCTION}

The Southern Karaman sheep is described as a separate breed formed as a result of the crossbreeding of the Karagül male sheep with the Akkaraman and Dağlıç sheep brought by the Yörüks (Türkmens) who migrated from Turkistan to the Mediterranean during the Ottoman period. The Suthern Karaman sheep is very productive in terms of meat and milk and it is often preferred in livestock breeding [10, 13]. The Hasak sheep is a breed formed by the triple cross-

Address for correspondence: H. Kara, PhD, Department of Anatomy, Faculty of Veterinary Medicine, Ataturk University, Erzurum 25240, Turkey, tel: +904422317188, e-mail: h.goktas@atauni.edu.tr

This article is available in open access under Creative Common Attribution-Non-Commercial-No Derivatives 4.0 International (CC BY-NC-ND 4.0) license, allowing to download articles and share them with others as long as they credit the authors and the publisher, but without permission to change them in any way or use them commercially. 
breeding of the German Black-headed, Hampshire and Akkaraman breeds at the Konya Bahri Dagdas International Agricultural Institute [13, 19, 21].

In ruminants, the arterial feeding of the forelimb is provided by the arteria axillaris, a continuation of the arteria subclavia, the branch of truncus brachiocephalicus that emerges from the arcus aorta $[7,15]$. The arteria subclavia dexter et sinister originate from the chest cavity and after their passage to the forelimb, the section up to the musculus teres major beam is referred to as the arteria axillaris. Arteria axillaris is divided into two main branches, proximal and distal, at the level of articulatio humeri. On the musculus subscapularis of arteria axillaris, the thickest of the branches that travel proximal along the margo caudalis of the scapula and emerge from arteria axillaris are referred to as arteria subscapularis. The distal part of arteria axillaris from the chorda of musculus teres major to collum radii is called arteria brachialis [4,6]. The distal part of arteria brachialis after collum radii is named to as arteria mediana $[3,11,15]$. The branches of arteria subscapularis are arteria thoracodorsalis, arteria circumflexa humeri caudalis and arteria circumflexa scapula. In addition to these branches, many rami muscularis are also among the branches separated. Arteria profunda brachii, arteria bicipitalis, arteria collateralis ulnaris, arteria brachialis superficialis, arteria transversa cubiti, arteria interossea communis, arteria ulnaris branches originate from arteria brachialis $[4,6]$.

The aim of this study was to examine the morphological structure of the forelimb arteries in the Southern Karaman and Hasak sheep.

\section{MATERIALS AND METHODS}

Totally, 8 Southern Karaman and 8 Hasak sheep used in this study were obtained from Konya Bahri Dagdas International Agriculture Institute. The sheep were anesthetised with xylazine $\mathrm{HCl}(0.2 \mathrm{mg} / \mathrm{kg} / \mathrm{lV})$ and ketamine $\mathrm{HCl}(2.2 \mathrm{mg} / \mathrm{kg} / \mathrm{lV})$ [18] and extravasated by cutting the arteria carotis communis in the neck area of the sheep. Then, the body cavity along the median line was opened and the internal organs were removed. Latex, which is described as the raw material of rubber mixed with red dye, was given into arteria axillaris with injectors of various sizes depending on vessel diameter and then left in $10 \%$ formaldehyde solution for fixation for 72 hours after applying latex injection method [1, 2, 8, 9, 22]. Then the forelimb arteries were examined individually and their anatomical structures, routes and branches were examined and each photographed separately. Nomina Anatomica Veterinaria [23] was based on the naming of the vessels.

\section{RESULTS}

In both breeds studied, arteria axillaris was identified at the level of articulatio humeri to divide into two main branches, namely arteria brachialis, which ran along the limb distally in the triangular area between musculus subscapularis and musculus teres major, and arteria subscapularis, which ran towards the scapula in the caudodorsal direction. The branches of arteria subscapularis which ran along the margo caudalis of the scapula were arteria circumflexa humeri caudalis, arteria thoracodorsalis, ramus tricipitis and arteria circumflexa scapula (Fig. 1A, B). The first branch of the arteria subscapularis, which continued in proximal, was identified as arteria circumflexa humeri caudalis, which gave it towards the front of the limb. It was determined that arteria circumflexa humeri caudalis navigated between musculus brachialis and musculus triceps brachii immediately after its origin. The second branch of arteria subscapularis was arteria thoracodorsalis. This branch originated from the same place as arteria circumflexa humeri caudalis, moving in different directions and within $1 \mathrm{~cm}$ proximal of the beginning of arteria brachialis and in the caudal direction. It was determined to continue between musculus latissimus dorsi and musculus teres major. Later, the arteria subscapularis was found to give thin muscular branches in the cranial direction, with 3 in the Southern Karaman sheep and 2 in the Hasak sheep. After giving the second of these branches in the Southern Karaman sheep and the first in the Hasak sheep, it was determined that the ramus tricipitis originated to feed musculus triceps brachii and run caudal, i.e. in the caudal direction as arteria thoracodorsalis. In its further course, arteria subscapularis gave arteria circumflexa scapula, which run laterally, along the scapula's margo cranialis, to feed musculus supraspinatus and musculus subscapularis (Fig. 1A, B).

Arteria circumflexa humeri cranialis, arteria profunda brachii, arteria collateralis ulnaris, arteria bicipitalis, arteria transversa cubiti, arteria interosseous communis branches were found to originate from arteria brachialis and continue distally as arteria mediana. It was observed that the first branch separated from the arteria brachialis was the arteria circumflexa 

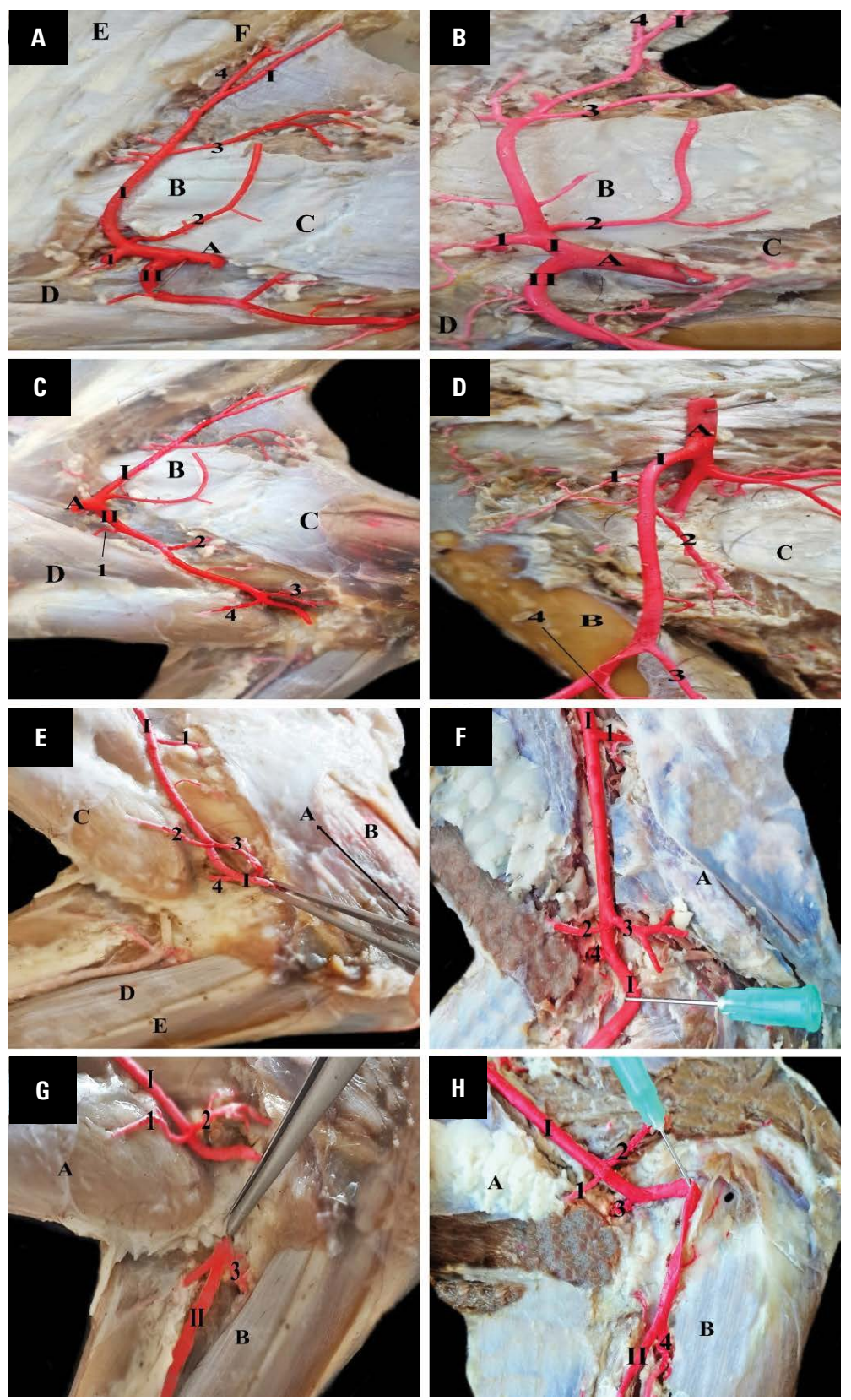

Figure 1. The branches of arteria brachialis and arteria subscapularis in Southern Karaman and Hasak sheep; A. Arteria subscapularis and its branches in Southern Karaman sheep, A - arteria axillaris, B - musculus teres major, C - musculus triceps brachii, D - musculus biceps brachii, E - musculus supraspinatus, $\mathrm{F}$ - musculus subscapularis, I - arteria subscapularis, II — arteria brachialis, 1 - arteria circumflexa humeri caudalis, 2 - arteria thoracodorsalis, 3 - ramus tricipitis, 4 - arteria circumflexa scapula; B. Arteria subscapularis and its branches in Hasak sheep, A - arteria axillaris, B - musculus teres major, C - musculus triceps brachii, D - musculus biceps brachii, I - arteria subscapularis, II - arteria brachialis, 1 - arteria circumflexa humeri caudalis, 2 - arteria thoracodorsalis, 3 - ramus tricipitis, 4 - arteria circumflexa scapula; C. Arteria brachialis and its branches in Southern Karaman sheep, A - arteria axillaris, B - musculus teres major, C - musculus triceps brachii, D - musculus biceps brachii, I - arteria subscapularis, II - arteria brachialis, 1 - arteria circumflexa humeri cranialis, 2 - arteria profunda brachii, 3 - arteria collateralis ulnaris, 4 - arteria bicipitalis; D. Arteria brachialis and its branches in Hasak sheep, A - arteria axillaris, B - os femur, C - musculus triceps brachii, I - arteria brachialis, 1 - arteria circumflexa humeri cranialis, 2 - arteria profunda brachii, 3 - arteria collateralis ulnaris, 4 - arteria bicipitalis; $\mathbf{E}$. Arteria transversa cubiti in Southern Karaman sheep, A - articulatio cubiti, B - musculus triceps brachii, C - musculus biceps brachii, D - musculus flexor carpi radialis, I - arteria brachialis, 1 - arteria profunda brachii, 2 - arteria bicipitalis, 3 - arteria collateralis ulnaris, 4 - arteria transversa cubiti; F. Arteria transversa cubiti in Hasak sheep, A - musculus triceps brachii, I - arteria brachialis, 1 - arteria profunda brachii, 2 - arteria bicipitalis, 3 arteria collateralis ulnaris, 4 - arteria transversa cubiti; G. Arteria interossea communis in Southern Karaman sheep, A - musculus biceps brachii, B - musculus flexor carpi radialis, I - arteria brachialis, II - arteria mediana, 1 - arteria bicipitalis, 2 - arteria collateralis ulnaris, 3 - arteria interossea communis; H. Arteria interossea communis in Hasak sheep, A - musculus biceps brachii, B - musculus flexor carpi radialis, I - arteria brachialis, II - arteria mediana, 1 - arteria bicipitalis, 2 - arteria collateralis ulnaris, 3 - arteria transversa cubiti, 4 arteria interossea communis. 
humeri cranialis in order to feed the musculus biceps brachii. It was determined that this branch run towards the craniolateral aspect of the limb. It was determined that arteria brachialis gave arteria profunda brachii on the distal part of tuberositas teres major (Fig. 1C-H). It was seen that after giving this branch, arteria brachialis gave thin muscular branches which continued in the same direction as it. Later, it was observed that two branches originating from the arteria brachialis that they continued in different directions. The branch that continued in the cranial direction was arteria bicipitalis and the branch that continued in the caudal direction was arteria collateralis ulnaris. Arteria collateralis ulnaris followed along the distal edge of musculus triceps brachii. It was determined that arteria bicipitalis was dispersed in musculus biceps brachii to feed it. Arteria brachialis was observed to give arteria transversa cubiti at the level of articulatio cubiti. Arteria brachialis gave its last branch, arteria interossea communis, at the level of the spatium interosseum antebrachii proximalis, then continued as the arteria mediana, cruising along the distal of the limb (Fig. 1E-H).

\section{DISCUSSION}

In mammals [6], it was reported that arteria axillaris was a continuation of the arteria subclavian and that arterial vascularisation of the forearm was provided by this vessel [17]. Arteria axillaris was found at the level of articulatio humeri [4]. Similar to us, previous report found that it continued towards the scapula with the name arteria subscapularis and arteria brachialis, which ran along the distal part of the limb [4].

Arteria circumflexa humeri caudalis have been reported to originate from arteria subscapularis [15, $16]$ and originate from the same place as arteria thoracodorsalis in ruminant [20]. Our results were similar to those of the literature.

Similar to our findings, previous studies [6, 14-17] reported that arteria thoracodorsalis originated from arteria subscapularis with the origin of arteria circumflexa humeri caudalis. However, unlike our findings, other previous study was reported that arteria thoracodorsalis originated from the dorsal wall of arteria axillaris [5].

The arteria subscapularis in the Southern Karaman and Hasak sheep continued its path as arteria circumflexa scapula after giving off arteria thoracodorsalis; it was also determined by Dursun [4] and Nickel [14].
Previous studies suggested that arteria brachialis continues as arteria mediana along the leg after giving the branch of arteria Intersosseous communis $[5,11,17]$. Nur and Ari [17] reported that the arteria interosseous cranialis branch arises instead of the arteria interosseous communis branch, one of the branches separated from the arteria brachialis. It has been determined our findings differed from those of Nur and Ari [17], and showed similarities with other literature $[5,11]$.

Arteria circumflexa humeri cranialis at the proximal level of the humerus was reported to originate from the axial arteries of the medial face [6]. In addition, Nickel [14] reported that arteria circumflexa humeri cranialis originated from arteria brachialis. Our study findings were in line with the findings of Nickel [14], while they differ from those of Dursun [6].

According to Nur et al. [16] and Getty [11], arteria profunda brachii originated from arteria brachialis and according to Dursun [6] it was the first branch of arteria brachialis. Our study findings were similar to those in the literature, but differently, it was not the first branch of the arteria brachialis, but the second branch from the arteria brachialis that emerged after the arterial circumflexa humeri cranialis.

Similar to our study findings, it was reported that arteria collateralis ulnaris was a branch emerging from arteria brachialis and that it was distributed to musculus triceps brachii and arteria bicipitalis was distributed to musculus biceps brachii $[4,5,17]$.

Ghoshal and Getty [12] determined that the palmar branch of the cranial interosseous artery passes through the distal interosseous space of the forearm and divides into a superficial and deep branch in goats [12]. Nickel noticed arterial communication between a branch of Ramus volaris profundus and a branch of arteria medianoradialis in three cases [14]. Also, Dursun [4] reported that arteria interosseous communis originated from arteria brachialis at the level of spatium interosseum antebrachii proximalis. In our study, arteria interosseous communis branches were found to originate from arteria brachialis and continue distally as arteria mediana.

\section{CONCLUSIONS}

In conclusion, the forelimb arteries in Southern Karaman and Hasak sheep breeds were found similar in regards of structure and morphology to the sheep breeds and some mammals. In addition to the ana- 
tomical findings, this also will contribute to scientific studies on the forelimb arteries in the sheep breeds.

\section{REFERENCES}

1. Aycan K, Bilge A. Plastik enjeksiyon ve korozyon metodu ile vasküler system anatomisinin araştırılması. ErciyesÜniv Tıp FakDerg. 1984; 614: 545-552.

2. Buggei JA. standardisedplastik injection technique for anatomical purposes. Acta Anat. 1963; 51: 177-192.

3. Doğuer S. Evcil hayvanların komparatif sistematik anatomisi: dolaşım sistemi-angiologia. Anakara Univ Vet Fak Yay, Anakara Univ Basımevi, Ankara 1970.

4. Dursun N. Veteriner Komparatif Anatomi Dolasım Sistemi (Angiologia). A.Ü. Vet. Fak. Yayınları, Ankara 1981.

5. Dursun N, Tıpırdamaz S, Gezici M. Köpeklerde ön ekstremitenin arterial vaskularizasyonu, S Ü Vet Fak Derg. 1989; 5(1): 175-189.

6. Dursun N. Veteriner Anatomi II. Medisan Yayın, Ankara 1994.

7. Dyce KM, Sack WO, Wensing CJG. Text book of veterinary anatomi. WB Saunders Company, Philadelphia 1987.

8. Ekim O, Tunalı S. Hazıroğlu Merih R. Evcil memeli hayvanlarda böbreklerin soğuk ortam tekniği ile silicon plastinasyonu. Vet Hekim Der Derg. 2014; 85(2): 1-11.

9. Erençin Z, Hassa O, Sağlam M, et al. Enjeksiyon yoluyla damar ve kanal sistemleri için plastic demonstrasyon metodlarının geliştirilmesi. Ankara Üniv Vet Fak Derg. 1967; 14(3): 444-452.

10. Ertuğrul M, Dellal G, Soysal I, et al. Türkiye Yerli Koyun Irklarının Korunması, Bursa Uludağ Üniversitesi Ziraat Fakültesi Dergisi. 2009; 23(2): 97-119.

11. Getty R. Sisson and Grossman's the anatomy of the domestic animals. 5th ed. WB Saunders Co, London 1975.
12. Ghoshal NG, Getty R. The arterial supply to appendages of the goat (Capra hircus). lowa State University Veterinarian, 1967; 29(3):123-144.

13. Kaymakçı M, Taşkın T. Türkiye Koyunculuğunda Melezleme Çalışmaları. Hayvansal Üretim. 2008; 49(2): 43-51.

14. Nickel W. Arterien und Venen der Vordergliedmasse der Ziel(e. Dissertation, Hannover, Germany, Tierarztliche Hochschule. 1962.

15. Nickel R, Schummer A, Seiferle E. The anatomy of the domestic animals. Werlag Paul Parey, Berlin 1981.

16. Nur ï, Karadağ H, Arı HH, et al. Yenizellenda tavşanlarında Arteria Axillaris ve Dalları Üzerinde Makroanatomik Bir Çalışma. F Ü Sağlık Bil Derg. 1995; 9(2): 189-195.

17. Nur iH, Arı HH. Van kedilerinde ön kolun arterial donanımı üzerinde makroanatomik ve subgros bir çalışma. YYÜ Vet Fak Derg. 2000; 11: 93-103.

18. Özüdoğru Z, Aksoy G. Tuj koyununun ön bacak venaları üzerine makroanatomik bir çalışma. Kafkas Univ Vet Fak Derg. 2009; 15(5): 771-778.

19. Teke BE, Özüdoğru Z, Özdemir D, et al. Hasak Koyunlarında Kalp Kas Köprüleri ve Koroner Arterler. J Bahri Dagdas Animal Res. 2017; 6(1): 1-12.

20. Popesko P. Atlas of the topographical anatomy of the domestic animals 1975.

21. Sönmez R, Kaymakçı M, Eliçin A, et al. Türkiye Koyun Islahı Çalışmaları. Bursa Uludağ Üniversitesi Ziraat Fakültesi Dergisi. 2009; 23(2): 43-65.

22. Tekdemir I, Uz A, Tüccar E, et al. Vasküler Anataomi Çalışmalarında Renklendirilmiş Lateks Uygulaması. AU Tıp Fakültesi Derg. 1999; 52(1): 23-26.

23. World Association of Veterinary Anatomists. International Committee on Veterinary Gross Anatomical Nomenclature. Nomina anatomica veterinaria. Hannover; Columbia [Mo.]; Ghent; Sapporo: The Editorial Committee, 2005. 